\title{
Financial Strain Is Associated with Malnutrition Risk in Community-Dwelling Older Women
}

\author{
Laura J. Samuel, ${ }^{1}$ Sarah L. Szanton, ${ }^{1}$ Carlos O. Weiss, ${ }^{2}$ Roland J. Thorpe Jr., ${ }^{3}$ \\ Richard D. Semba, ${ }^{4}$ and Linda P. Fried ${ }^{5}$ \\ ${ }^{1}$ School of Nursing, Johns Hopkins University, Baltimore, MD 21205, USA \\ ${ }^{2}$ Division of Geriatric Medicine and Gerontology, Johns Hopkins Medicine, Baltimore, MD 21205, USA \\ ${ }^{3}$ Department of Health Policy and Management, Bloomberg School of Public Health, Baltimore, MD 21205, USA \\ ${ }^{4}$ Department of Ophthalmology, Johns Hopkins School of Medicine, Baltimore, MD 21287, USA \\ ${ }^{5}$ Department of Epidemiology, Mailman School of Public Health, Columbia University, New York, NY 10032, USA
}

Correspondence should be addressed to Laura J. Samuel, lsamuel@jhmi.edu

Received 25 February 2012; Revised 16 August 2012; Accepted 24 September 2012

Academic Editor: Chit Ming Wong

Copyright ( 12012 Laura J. Samuel et al. This is an open access article distributed under the Creative Commons Attribution License, which permits unrestricted use, distribution, and reproduction in any medium, provided the original work is properly cited.

\begin{abstract}
This study examined the relationship between financial strain, or difficulty acquiring necessities, and malnutrition risk in a community dwelling sample of frail and nonfrail women aged 70-79 in the Women's Health and Aging Study ( $n=679$ ). Malnutrition risk was measured with a modified version of the Mini-Nutritional Assessment Short Form (MNA-SF) and defined as a score $<11$, financial strain was measured by (1) sufficiency of money on a monthly basis and (2) adequacy of income for food, and income was measured by ordinal categories. Mean (SD) modified MNA-SF score was 12.2 (1.80), and 14.7\% of women had malnutrition risk. Women who usually did not have enough money to make ends meet had more than four-fold increased odds of malnutrition risk ( $\mathrm{OR}=4.54 ; 95 \% \mathrm{CI}: 2.26,9.14)$ compared to their counterparts who had some money left over each month. This was only slightly attenuated after control for income and education, $(\mathrm{OR}=4.08 ; 95 \% \mathrm{CI}: 1.95,8.52)$ remaining robust. These results show an association between financial strain and malnutrition risk, independent of income, in older women. Self-reported financial strain may be preferable to income as a screener for malnutrition risk in older adults in clinical and research settings.
\end{abstract}

\section{Introduction}

Malnutrition, which is a risk factor for disability and mortality, $[1,2]$ poses a burden for community dwelling older adults, particularly those of low socioeconomic status. Exact rates of this often undiagnosed condition are difficult to estimate in this population [3-5], but an estimated $9 \%$ of community dwelling older adults are malnourished and up to $45 \%$ have malnutrition risk and should have clinical diagnostic evaluation [6]. Rates are consistently higher, however, among low income compared to high income individuals $[3,7,8]$. Malnutrition is generally understood to be a deficiency of both energy and protein, combined with decreased fat-free mass [9], although older adults of low socioeconomic status can be malnourished even if consuming a high energy diet $[10,11]$, probably because they consume foods with lower nutrient content $[10,12]$. Also, there is evidence that food insecure adults, or adults who lack regular access to food, have poorer dietary quality than food secure adults, despite similar caloric intake [11, 13-15].

Although income is associated with malnutrition, income alone may not accurately predict malnutrition in older adults, since cost of living, household size, and competing needs cause variation in the purchasing power of retirees [16]. Rising health care costs push many older adults into poverty, even if their absolute income is above the poverty line [17]. In addition, many older adults whose income is above the poverty level still lack regular access to food [14]. Also, income alone does not capture financial assets, such as wealth [17]. Therefore, socioeconomic measures in older adults should consider the inadequacy of income to obtain basic necessities, along with absolute income [18]. 
Self-reported financial strain, or difficulty acquiring basic necessities and meeting financial obligations [19], is related to income but also captures the balance of income to need [18]. Financial strain is associated with other health outcomes, including mortality [18], self-rated health [20], cardiac events [21,22], depression [23], increased blood pressure [24], poorer sleep quality [25], and smoking relapse after cessation [26]. These associations remain independent of income. However, the relationship between financial strain and malnutrition is unknown. Therefore, the purpose of this study is to determine if financial strain is associated with malnutrition risk in older women and to compare the associations of financial strain with that of income for malnutrition risk.

\section{Methods}

2.1. Sample. Data for this study were taken from the Women's Health and Aging Study I and II (WHAS I and II), which examined the causes and progression of disability and frailty. Both samples in this study used age-stratified random sampling of community-dwelling women living in a 12 zipcode area in and around Baltimore, MD. The first cohort, WHAS I, which has been described elsewhere [27, 28], recruited 1002 women aged 65 and older, who were among the one-third most disabled of their age cohort (conducted from 1992-1995). The second cohort, WHAS II, consisted of 436 women aged 70 to 79 , who were among the two-thirds least disabled (conducted from 1994-1996) and has also been described elsewhere [29]. The current study is a crosssectional analysis of baseline data from both WHAS I and WHAS II using sampling weights, to create a representative sample of women aged 70-79. Women between these ages with complete financial strain, income, and outcome data were included in this analysis $(n=679)$. The Johns Hopkins School of Medicine Institutional Review Board approved the research protocols. Each participant provided written informed consent.

\subsection{Study Variables}

2.2.1. Outcome. The Mini Nutritional Assessment Short Form (MNA-SF) is a shortened form of the well-established Mini Nutritional Assessment [7]. The MNA-SF shows high sensitivity and specificity as a screener to identify individuals who have malnutrition risk and is able to detect malnutrition before weight loss or decreased serum albumin $[6,30]$. The questionnaire assesses the following six domains that are associated with malnutrition risk: recent decreased intake, including loss of appetite or decreased intake due to difficulty chewing or swallowing; recent unintentional weight loss; diminished mobility; recent psychological distress or acute illness; neuropsychological problems (either dementia or depression); low body mass index (BMI), as assessed by height and weight measurements (See Table 5 for details). Scores for all domains are summed, ranging from 0-14; scores 11 to 14 indicate normal nutritional status and $<11$ indicate malnutrition risk, meaning that the individual should undergo a further clinical evaluation for malnutrition diagnosis [30]. Three domains were adapted slightly to the variables available in this dataset, as summarized in Table 5 . Briefly, WHAS does not include questions specific to the past three months for the "appetite loss," "weight loss," and "psychological distress or illness" categories. Instead, these were approximated by usual appetite, weight loss in past year and/or percentage of weight lost since age 60, and psychological distress in past year or acute illness in past two weeks, respectively.

2.2.2. Main Independent Variable. Financial strain was assessed by using ordinal responses to two questions. Participants were asked "At the end of the month, do you have some money left over, just enough, or not enough." This measure has been used in prior work [18] and is taken from a longer financial strain instrument, which was shown to be correlated with job disruption, economic coping and depression [19]. The second question, chosen for theoretical relevance to malnutrition, was "How often is your income not adequate for food," with response options of "never," "once in a while," "fairly often," or "very often." These latter two response options were collapsed due to small cell counts.

2.2.3. Covariates. Participants reported demographic factors, including age, race (white or black), marital status (married, widowed, divorced/separated, and never married), years of education completed (0 to 18), and annual household income, which was collapsed to ordinal categories according to linear splines with modified MNA-SF scores: $<\$ 6,000$ (which also approximates the contemporaneous poverty threshold for older adults [31]), \$6,000-9,999, \$10,00024,999 and $\geq \$ 25,000$. Additional individual characteristics that may be associated with both financial strain and malnutrition risk were also considered in multivariate analysis. These included participation in the Food Stamp Program $[32,33]$ and diagnosis of congestive heart failure or cancer. Difficulty driving was also considered since this may limit access to nutritionally dense foods for low income adults in urban areas $[34,35]$.

2.3. Data Analysis. Mean and proportional differences for the demographic and financial strain characteristics were evaluated with Pearson Chi square and $t$-tests, as appropriate, comparing those having malnutrition risk and those not having malnutrition risk. The odds of having malnutrition risk were modeled using progressively extended logistic regression models, separately for both financial strain variables. Covariates were added in the following way: Model 1 included financial strain, Model 2 added income and education, and Model 3 added age, race, and marital status. Interaction terms were tested for financial strain with race, age and Food Stamp Program participation and retained if significant. Additional individual characteristics were included in models if they altered the relationship between financial strain and malnutrition risk. Tests were conducted for collinearity between financial strain and either income or education. Probability weights were used to account for 
TABLE 1: Distribution of sociodemographic variables by malnutrition risk status (modified MNA-SF $<11)$ in WHAS I and II $(n=679)$.

\begin{tabular}{|c|c|c|c|}
\hline Variable & Modified MNA-SF $<11, n=99^{\mathrm{b}}$ & Modified MNA-SF $11-14, n=580^{\mathrm{b}}$ & $P$ value ${ }^{\mathrm{a}}$ \\
\hline Age (SD) & $74.9(2.8)$ & $74.0(2.8)$ & 0.004 \\
\hline \multicolumn{4}{|l|}{ Race $(\%)$} \\
\hline White & $67(68)$ & $454(78)$ & \multirow{2}{*}{0.022} \\
\hline Black & $32(32)$ & $126(22)$ & \\
\hline \multicolumn{4}{|l|}{ Marital status (\%) } \\
\hline Married & $16(16)$ & $192(33)$ & \multirow{4}{*}{0.003} \\
\hline Widowed & $66(67)$ & $290(50)$ & \\
\hline Separated/divorced & $12(12)$ & $54(9)$ & \\
\hline Never married & $5(5)$ & $43(7)$ & \\
\hline Education Years (SD) & $10.2(3.7)$ & $11.7(5.9)$ & $<0.001$ \\
\hline \multicolumn{4}{|l|}{ Income $(\%)$} \\
\hline$\$ 25,000 \leq$ & $17(17)$ & $165(28)$ & \multirow{4}{*}{$<0.001$} \\
\hline$\$ 10,000-24,999$ & $25(25)$ & $214(37)$ & \\
\hline$\$ 6,000-9,999$ & $22(22)$ & $138(24)$ & \\
\hline$<\$ 6,000$ & $35(35)$ & $63(11)$ & \\
\hline \multicolumn{4}{|l|}{ Lack income for food $(\%)$} \\
\hline Never & $69(70)$ & $505(87)$ & \multirow{3}{*}{$<0.001$} \\
\hline Once in a while & $19(19)$ & $56(10)$ & \\
\hline Fairly/very often & $11(11)$ & $19(3)$ & \\
\hline \multicolumn{4}{|l|}{ Finances at month end (\%) } \\
\hline Some money left & $45(45)$ & $386(67)$ & \multirow{3}{*}{$<0.001$} \\
\hline Just enough & $36(36)$ & $166(29)$ & \\
\hline Not enough to make ends meet & $18(18)$ & $28(5)$ & \\
\hline
\end{tabular}

${ }^{a} t$-test for continuous data or Pearson Chi square test of independence for categorical data.

${ }^{b}$ Percentages may not sum to 100 due to rounding.

age, race, and disability and account for age stratification and non-response, as has been previously described [27]. Data were analyzed using Stata 10 [36].

\section{Results}

Comparing participants included in this analysis to those missing data, there were no significant differences by financial strain, age, or education. However, the participants included in the sample were less likely to have a low income ( $14 \%$ versus $40 \%$ had $<\$ 6,000$ annually, $P=0.008$ ), less likely to be black ( $23 \%$ versus $31 \%, P=0.036$ ), and more likely to be widowed ( $52 \%$ versus $35 \%, P=0.001$ ). Sample characteristics are provided in Table 1. Mean modified MNASF scores in this sample were in the normal nutritional status range $($ mean $=12.2, \mathrm{SD}=1.80)$ and $14.7 \%$ of the women had malnutrition risk. There were significant differences in malnutrition risk across age, race, income, and education categories as Table 1 shows. Approximately 15\% of women reported that they lacked income for food at least "once in a while," and 4\% reported that this occurred "fairly" or "very often." Also, 30\% of the women reported that they had just enough money to make ends meet on a monthly basis, and another $7 \%$ reported they usually did not have enough money. In this sample, only 5\% received Food Stamps, and of the 115 women reporting ever lacking income for food, only $21 \%$ received Food Stamps. Income was moderately correlated with both lacking money for food and difficulty making ends meet (Spearman's $\rho=-0.40, P<0.05$, for both).

Financial strain was associated with malnutrition risk, when measured either as lacking money for food or difficulty making ends meet. Women who reported fairly or very often lacking money for food had greater than four times increased odds of malnutrition risk compared with women who never lacked money for food (Table 2). This relationship remained statistically significant, but attenuated after controlling for income and education and other covariates in the model, so that individuals who often lacked money for food had approximately three times increased odds of malnutrition risk. Financial strain demonstrated a gradient of association, with a positive, though statistically nonsignificant association for those who only sometimes lacked money for food, and stronger association for individuals who often lacked money for food. However, income was significantly associated with malnutrition risk only for individuals with income below the poverty threshold, and education was not statistically significant.

Similar results were obtained for those who reported they usually did not have enough to make ends meet (Table 3 ). These individuals had more than four times increased odds of malnutrition risk than those who had some money left over monthly in unadjusted analysis. After controlling for 
TABLE 2: Multivariable logistic regression analyses of the relationship between lack of income for food and malnutrition risk in women aged $70-79(n=679)$.

\begin{tabular}{|c|c|c|c|}
\hline & $\begin{array}{c}\text { Model } 1 \\
\text { OR }(95 \% \text { CI })\end{array}$ & $\begin{array}{c}\text { Model } 2 \\
\text { OR }(95 \% \text { CI })\end{array}$ & $\begin{array}{c}\text { Model } 3 \\
\text { OR }(95 \% \text { CI })\end{array}$ \\
\hline \multicolumn{4}{|l|}{ Lack income for food } \\
\hline Never (ref) & - & - & - \\
\hline Once in a while & $2.24(1.23,4.10)$ & $1.52(0.78,2.96)$ & $1.61(0.83,3.10)$ \\
\hline Fairly/very often & $4.31(1.94,9.57)$ & $2.73(1.14,6.56)$ & $2.98(1.15,7.73)$ \\
\hline Education (years) & & $1.00(0.94,1.04)$ & $0.99(0.95,1.04)$ \\
\hline \multicolumn{4}{|l|}{ Income } \\
\hline$\$ 25,000 \leq(\mathrm{ref})$ & & - & - \\
\hline$\$ 10,000-24,999$ & & $0.90(0.44,1.86)$ & $0.84(0.41,1.71)$ \\
\hline$\$ 6,000-9,999$ & & $0.92(0.43,1.95)$ & $0.72(0.33,1.58)$ \\
\hline$<\$ 6,000$ & & $3.16(1.39,7.16)$ & $2.77(1.10,6.98)$ \\
\hline \multicolumn{4}{|l|}{ Other demographics } \\
\hline Age (years) & & & $1.11(1.02,1.21)$ \\
\hline \multicolumn{4}{|l|}{ Race } \\
\hline White (ref) & & & - \\
\hline Black & & & $0.82(0.45,1.52)$ \\
\hline \multicolumn{4}{|l|}{ Marital status } \\
\hline Married (ref) & & & - \\
\hline Widowed & & & $1.87(0.98,3.60)$ \\
\hline Separated/divorced & & & $1.55(0.54,4.42)$ \\
\hline Never married & & & $1.84(0.57,5.97)$ \\
\hline
\end{tabular}

income and education, the strength of the association for this financial strain question also remained robust, and, unlike income, also demonstrated a gradient of association.

Further analysis was conducted to determine which of the six domains of the modified MNA-SF were associated with financial strain (Table 4). Financial strain was correlated with decreased food intake, unintentional weight loss, and decreased mobility, neuropsychological problems, but not low BMI.

\section{Discussion}

Our findings show that financial strain may be more informative than income as an indicator of nutritional risk in older adults. These results contribute to the literature in two important ways. First, the study showed that financial strain, when measured either by lacking money for food or having difficulty making ends meet, was associated with increased odds of malnutrition risk in older adults even after control for two traditional socioeconomic measures: income and education. Also, this association showed a dose response gradient, while the association between income and malnutrition risk was only significant at the lowest income level of $<\$ 6,000$ annually. Interestingly, the contemporaneous poverty threshold for older adults was $\$ 7,309$ [31], indicating that the relationship between income and malnutrition risk may be explained solely by whether individuals are below or above the poverty threshold. These results indicate that income alone may not be a sufficient predictor of ability to acquire basic necessities and that financial strain may be a preferable socioeconomic measure in this sample of community-dwelling older adults. Financial strain is a more informative predictor of malnutrition risk, since it demonstrated a dose response in this sample. Also, financial strain was not strongly correlated with low BMI in this study but income was significantly associated with low BMI. Since there is growing evidence that malnutrition occurs in low socioeconomic status adults regardless of BMI $[10,11]$, financial strain may be preferable to income as a means of screening for nutritional risk in this population.

The reason for the dose response association between financial strain and malnutrition risk after control for income cannot be deduced from these results, but there are plausible reasons. A likely explanation is that the construct of financial strain draws upon both absolute income level and the finance-related perceived stress generated when individuals lack adequate income for their needs [41]. Financial stress has been associated with adverse health outcomes [42, 43]. General stress has a long, consistent and strong association with adverse health [44] and is thought to mediate the relationship between low socioeconomic status and poor health [45]. An alternative explanation is that income and education do not accurately reflect the adequacy of household resources, since they do not capture the balance of financial supply and demand $[18,46]$. Income reflects only 
TABLE 3: Multivariable logistic regression analyses of the relationship between difficulty making ends meet and malnutrition risk in women aged $70-79(n=679)$.

\begin{tabular}{|c|c|c|c|}
\hline & $\begin{array}{c}\text { Model } 1 \\
\text { OR }(95 \% \text { CI })\end{array}$ & $\begin{array}{c}\text { Model } 2 \\
\text { OR (95\% CI) }\end{array}$ & $\begin{array}{c}\text { Model } 3 \\
\text { OR }(95 \% \text { CI })\end{array}$ \\
\hline \multicolumn{4}{|l|}{ Monthly finances } \\
\hline Some money left (ref) & - & - & - \\
\hline Just enough to make ends meet & $1.80(1.08,3.00)$ & $1.42(0.83,2.44)$ & $1.54(0.88,2.68)$ \\
\hline Not enough to make ends meet & $4.55(2.26,9.14)$ & $3.62(1.75,7.48)$ & $4.08(1.95,8.52)$ \\
\hline Education (years) & & $1.00(0.95,1.04)$ & $1.00(0.96,1.03)$ \\
\hline \multicolumn{4}{|l|}{ Income } \\
\hline$\$ 25,000 \leq$ (ref) & & - & - \\
\hline$\$ 10,000-24,999$ & & $0.90(0.43,1.86)$ & $0.81(0.40,1.66)$ \\
\hline$\$ 6,000-9,999$ & & $0.80(0.37,1.72)$ & $0.60(0.27,1.32)$ \\
\hline$<\$ 6,000$ & & $3.06(1.41,6.60)$ & $2.54(1.07,5.99)$ \\
\hline \multicolumn{4}{|l|}{ Other demographics } \\
\hline Age (years) & & & $1.12(1.03,1.22)$ \\
\hline \multicolumn{4}{|l|}{ Race } \\
\hline White (ref) & & & - \\
\hline Black & & & $0.85(0.47,1.54)$ \\
\hline \multicolumn{4}{|l|}{ Marital status } \\
\hline Married (ref) & & & - \\
\hline Widowed & & & $1.91(0.99,3.69)$ \\
\hline Separated/divorced & & & $1.74(0.63,4.79)$ \\
\hline Never married & & & $1.88(0.57,6.21)$ \\
\hline
\end{tabular}

TABLE 4: Relationship (Spearman correlation or Chi square test) between socioeconomic measures with each of the 6 domains in the modified Mini Nutritional Assessment Short Form (MNA-SF), in women aged 70-79 $(n=679)$.

\begin{tabular}{lccc}
\hline & Income & Lacking money for food & Difficulty making ends meet \\
\hline Recent decreased intake & $\rho=-0.21^{*}$ & $\rho=-0.13^{*}$ & $\rho=-0.16^{*}$ \\
Recent unintentional weight loss & $\rho=-0.08^{*}$ & $\rho=-0.10^{*}$ & $\rho=-0.07$ \\
Diminished mobility & $\rho=-0.17^{*}$ & $\rho=-0.23^{*}$ & $\rho=-0.20^{*}$ \\
Recent psychological distress or acute illness & $\chi_{3}^{2}=6.96$ & $\chi_{2}^{2}=2.04$ & $\chi_{2}^{2}=1.67$ \\
Neuropsychological problems & $\rho=-0.23^{*}$ & $\rho=-0.20^{*}$ & $\rho=-0.28^{*}$ \\
Low body mass index & $\rho=0.09^{*}$ & $\rho=0.03$ & $\rho=0.06$ \\
\hline
\end{tabular}

${ }^{*} P<0.05$.

the financial input into the household but financial strain also captures competing demands for financial resources. Financial strain may be a more specific indicator than income of lack of other resources, such as wealth, available to individuals and this may be particularly true for older adults $[47,48]$. However, the relationship between financial strain and adverse health has also been found in younger samples [24-26, 49].

These results are limited by specific inclusion of urban and suburban older women, and may not be generalizable to men, younger adults, or to more rural areas, which could have differences in access to supermarkets or other food resources. However, there is a rationale for focusing on women, who are particularly susceptible to malnutrition and other adverse nutritional consequences of food insecurity $[15,50]$, and focusing on older adults, who are susceptible to both nutritional risk and to adverse consequences of it $[1,6,7,51]$. Another limitation was the low proportion of Food Stamp Program participation, limiting the ability to detect effect modification of the relationship between financial strain and malnutrition risk. This study was strengthened, however, by use of objectively measured BMI for malnutrition risk and use of a population-based sample.

These findings have clinical, public health, and research implications. Identification of predictors of malnutrition risk, such as financial strain, and timely identification of those factors in clinical practice may improve our ability to intervene in the aging process [52]. Also, income and 
TABle 5: Modifications to the Mini Nutritional Assessment Short Form (MNA-SF).

\begin{tabular}{|c|c|c|}
\hline & Original MNA-SF criteria and score [30] & WHAS modifications to MNA-SF criteria and score \\
\hline \multirow[b]{2}{*}{ A } & $\begin{array}{l}\text { Has food intake declined over the past } 3 \text { months due to } \\
\text { loss of appetite, digestive problems, chewing, or } \\
\text { swallowing difficulties? }\end{array}$ & $\begin{array}{l}\text { What is usual appetite? Any difficulty chewing or swallowing that limit } \\
\text { ability to eat? }\end{array}$ \\
\hline & $\begin{array}{l}0=\text { severe decrease in food intake } \\
1=\text { moderate decrease in food intake } \\
2=\text { no decrease in food intake }\end{array}$ & $\begin{array}{l}0=\text { appetite is usually poor or appetite is fair combined with problems } \\
\text { chewing/swallowing that limit ability to eat } \\
1=\text { fair appetite and no problems chewing/swallowing } \\
2=\text { good or very good appetite }\end{array}$ \\
\hline \multirow[b]{2}{*}{$\mathrm{B}$} & Weight loss during the last 3 months & $\begin{array}{l}\text { Weight loss during the past year and/or percentage of body weight lost } \\
\text { since age } 60\end{array}$ \\
\hline & $\begin{array}{l}0=\text { weight loss greater than } 3 \mathrm{~kg} \\
1=\text { does not know } \\
2=\text { weight loss between } 1 \text { and } 3 \mathrm{~kg} \\
3=\text { no weight loss }\end{array}$ & $\begin{array}{l}0=\text { reports either weight loss due to illness or weight loss in past year } \\
\text { combined with }>15 \% \text { of weight at age } 60 \text { is now lost } \\
1=\text { weight loss unknown } \\
2=\text { reports weight loss in past year combined with }<15 \% \text { of weight at } \\
\text { age } 60 \text { is lost } \\
3=\text { reports no weight loss in past year }\end{array}$ \\
\hline & Mobility & No modifications \\
\hline $\mathrm{C}$ & $\begin{array}{l}0=\text { bed or chair bound } \\
1=\text { able to get out of bed/chair but does not go out } \\
2=\text { goes out }\end{array}$ & $\begin{array}{l}0=\text { By his/herself, has difficulty getting in and out of bed or chairs } \\
1=\text { By his/herself, able to get in out of bed/chair, but does not leave the } \\
\text { house in a typical week } \\
2=\text { During typical week, goes outside the house and/or neighborhood }\end{array}$ \\
\hline \multirow{2}{*}{$\mathrm{D}$} & $\begin{array}{l}\text { Has suffered psychological stress or acute disease in the } \\
\text { past } 3 \text { months? }\end{array}$ & $\begin{array}{l}\text { Has suffered bereavement or seriously ill spouse in past year or acute } \\
\text { disease in past } 2 \text { weeks? }\end{array}$ \\
\hline & $\begin{array}{l}0=\text { yes } \\
2=\text { no }\end{array}$ & $\begin{array}{l}0=\text { yes } \\
2=\text { no }\end{array}$ \\
\hline \multirow[b]{2}{*}{$\mathrm{E}$} & Neuropsychological problems & No modifications \\
\hline & $\begin{array}{l}0=\text { severe dementia or depression } \\
1=\text { mild dementia } \\
2=\text { no psychological problems }\end{array}$ & $\begin{array}{l}0=\text { Mini Mental State Examination }(\text { MMSE) score }<17[37,38] \text { or } \\
\text { Geriatric Depression Scale score } 11 \leq[39,40] \\
1=\text { MMSE score } 17-24 \text { and Depression score }<11 \\
2=\text { MMSE score } 24<\text { and Depression score }<11\end{array}$ \\
\hline & Body mass index (BMI) & No modifications \\
\hline $\mathrm{F}$ & $\begin{array}{l}0=\mathrm{BMI}<19 \\
1=\mathrm{BMI} 19 \text { to }<21 \\
2=\mathrm{BMI} 21 \text { to }<23 \\
3=\mathrm{BMI} \geq 23\end{array}$ & $\begin{array}{l}\text { As described, according to clinically measured height at weight. If a } \\
\text { height measurement was not available it was estimated from the mean of } \\
\text { two measurements of knee to heel measurements, if these were } \\
\text { obtained, with the following formula as has been recommended [30]: } \\
\text { Estimated height }=(1.83 \times \text { knee height, } \mathrm{cm})-(0.24 \times \text { age })+84.88\end{array}$ \\
\hline
\end{tabular}

education continue to be used ubiquitously in research and policies, but this study and others $[47,48]$ have shown that they are not consistently associated with health outcomes in older adults. Attention to alternative socioeconomic measures, such as financial strain, may improve our ability to address nutritional risk in research, policies, and clinical practice for older adults.

This study found that a single screening question regarding financial strain may be useful in public health and primary care settings to identify individuals who have malnutrition risk and should receive formal clinical nutritional evaluation. This is important since one simple screening question on financial strain is feasible for clinical implementation and more likely to be answered by patients than questions about income. Based on these results, individuals who regularly experience financial strain are likely to be at increased malnutrition risk. In this study, individuals who reported either that they often did not have enough money to make ends meet or that they often lacked income for food had high likelihood of needing a clinical malnutrition evaluation. Timely identification of these individuals in public health and primary care settings is a critical step in effective nutritional intervention.

\section{Acknowledgments}

The authors thank the other investigators, staff, and participants of the Women's Health and Aging Studies for their valuable contributions. This work was supported by National Institutes of Health Grants 5T32NR007968-07, 1F31NR012087, R01AG11703, R01AG027012, and 1R37AG1990502; the Johns Hopkins Older Americans Independence Center (1P50AG 021334-01). 


\section{References}

[1] Institute of Medicine, Extending Life, Enhancing Life: A National Research Agenda on Aging, National Academies Press, Washington, DC, USA, 1991.

[2] Institute of Medicine, The Role of Nutrition in Maintaining Health in the Nation's Elderly: Evaluating Coverage of Nutrition Services for the Medicare Population, National Academies Press, Washington, DC, USA, 2000.

[3] A. Manson and S. Shea, "Malnutrition in elderly ambulatory medical patients," American Journal of Public Health, vol. 81, no. 9, pp. 1195-1197, 1991.

[4] M. M. G. Wilson, S. Vaswani, D. Liu, J. E. Morley, and D. K. Miller, "Prevalence and causes of undernutrition in medical outpatients," American Journal of Medicine, vol. 104, no. 1, pp. 56-63, 1998.

[5] M. Elia, L. Zellipour, and R. J. Stratton, "To screen or not to screen for adult malnutrition?" Clinical Nutrition, vol. 24, no. 6, pp. 867-884, 2005.

[6] Y. Guigoz, "The Mini Nutritional Assessment (MNA) review of the literature-what does it tell us?" Journal of Nutrition, Health and Aging, vol. 10, no. 6, pp. 466-485, 2006.

[7] Y. Guigoz, S. Lauque, and B. J. Vellas, "Identifying the elderly at risk for malnutrition the mini nutritional assessment," Clinics in Geriatric Medicine, vol. 18, no. 4, pp. 737-757, 2002.

[8] M. R. Lee and E. R. Berthelot, "Community covariates of malnutrition based mortality among older adults," Annals of Epidemiology, vol. 20, no. 5, pp. 371-379, 2010.

[9] J. M. M. Meijers, M. A. E. van Bokhorst-de van der Schueren, J. M. G. A. Schols, P. B. Soeters, and R. J. G. Halfens, "Defining malnutrition: mission or mission impossible?” Nutrition, vol. 26, no. 4, pp. 432-440, 2010.

[10] S. I. Kirkpatrick and V. Tarasuk, "Food insecurity is associated with nutrient inadequacies among Canadian adults and adolescents," Journal of Nutrition, vol. 138, no. 3, pp. 604-612, 2008.

[11] C. A. Zizza, P. A. Duffy, and S. A. Gerrior, "Food insecurity is not associated with lower energy intakes," Obesity, vol. 16, no. 8, pp. 1908-1913, 2008.

[12] J. S. Lee and E. A. Frongillo, "Nutritional and health consequences are associated with food insecurity among U.S. Elderly persons," Journal of Nutrition, vol. 131, no. 5, pp. 1503 1509, 2001.

[13] D. Rose and V. Oliveira, "Nutrient intakes of individuals from food-insufficient households in the United States," American Journal of Public Health, vol. 87, no. 12, pp. 1956-1961, 1997.

[14] D. Rose, "Economic determinants and dietary consequences of food insecurity in the United States," Journal of Nutrition, vol. 129, supplement 2, pp. 517S-520S, 1999.

[15] J. R. Sharkey, L. G. Branch, N. Zohoori, C. Giuliani, J. BusbyWhitehead, and P. S. Haines, "Inadequate nutrient intakes among homebound elderly and their correlation with individual characteristics and health-related factors," American Journal of Clinical Nutrition, vol. 76, no. 6, pp. 1435-1445, 2002.

[16] N. Krieger, D. R. Williams, and N. E. Moss, "Measuring social class in us public health research: concepts, methodologies, and guidelines," Annual Review of Public Health, vol. 18, pp. 341-378, 1997.

[17] B. A. Butrica, D. Murphy, and S. R. Zedlewski, How Many Struggle to Get by in Retirement? The Urban Institute, Washington, DC, USA, 2008.

[18] S. L. Szanton, J. K. Allen, R. J. Thorpe, T. Seeman, K. BandeenRoche, and L. P. Fried, "Effect of financial strain on mortality in community-dwelling older women," Journals of Gerontology, vol. 63, no. 6, pp. S369-S374, 2008.

[19] L. I. Pearlin, M. A. Lieberman, E. G. Menaghan, and J. T. Mullan, "The stress process," Journal of Health and Social Behavior, vol. 22, no. 4, pp. 337-356, 1981.

[20] S. L. Szanton, R. J. Thorpe, and K. Whitfield, "Life-course financial strain and health in African-Americans," Social Science and Medicine, vol. 71, no. 2, pp. 259-265, 2010.

[21] J. E. Ferrie, P. Martikainen, M. J. Shipley, and M. G. Marmot, "Self-reported economic difficulties and coronary events in men: evidence from the Whitehall II study," International Journal of Epidemiology, vol. 34, no. 3, pp. 640-648, 2005.

[22] A. Georgiades, I. Janszky, M. Blom, K. D. László, and S. Ahnve, "Financial strain predicts recurrent events among women with coronary artery disease," International Journal of Cardiology, vol. 135, no. 2, pp. 175-183, 2009.

[23] N. Krause, "Chronic financial strain, social support, and depressive symptoms among older adults," Psychology and Aging, vol. 2, no. 2, pp. 185-192, 1987.

[24] A. Steptoe, L. Brydon, and S. Kunz-Ebrecht, "Changes in financial strain over three years, ambulatory blood pressure, and cortisol responses to awakening," Psychosomatic Medicine, vol. 67, no. 2, pp. 281-287, 2005.

[25] M. H. Hall, K. A. Matthews, H. M. Kravitz et al., "Race and financial strain are independent correlates of sleep in midlife women: the SWAN sleep study," Sleep, vol. 32, no. 1, pp. 73-82, 2009.

[26] D. E. Kendzor, M. S. Businelle, T. J. Costello et al., "Financial strain and smoking cessation among racially/ethnically diverse smokers," American Journal of Public Health, vol. 100, no. 4, pp. 702-706, 2010.

[27] The Women's Health and Aging Study: Health and Social Characteristics of Older Women with Disability, National Institute on Aging, Bathesda, Md, USA, 1995.

[28] J. D. Kasper, S. Shapiro, J. M. Guralnik, K. J. Bandeen-Roche, and L. P. Fried, "Designing a community study of moderately to severely disabled older women: the Women's Health and Aging Study," Annals of Epidemiology, vol. 9, no. 8, pp. 498507, 1999.

[29] L. P. Fried, K. Bandeen-Roche, P. H. M. Chaves, and B. A. Johnson, "Preclinical mobility disability predicts incident mobility disability in older women," Journals of Gerontology, vol. 55, no. 1, pp. M43-M52, 2000.

[30] L. Z. Rubenstein, J. O. Harker, A. Salvà, Y. Guigoz, and B. Vellas, "Screening for undernutrition in geriatric practice: developing the Short-Form Mini-Nutritional Assessment (MNA-SF)," Journals of Gerontology, vol. 56, no. 6, pp. M366M372, 2001.

[31] E. Baugher and L. Lamison-White, Poverty in the United States: 1995, Current Population Reports, Series P60-194, U.S. Bureau of the Census, Washington, DC, USA, 1996.

[32] K. Kim and E. A. Frongillo, "Participation in food assistance programs modifies the relation of food insecurity with weight and depression in elders," Journal of Nutrition, vol. 137, no. 4, pp. 1005-1010, 2007.

[33] J. S. Lee and E. A. Frongillo, "Understanding needs is important for assessing the impact of food assistance program participation on nutritional and health status in U.S. elderly persons," Journal of Nutrition, vol. 131, no. 3, pp. 765-773, 2001.

[34] J. N. Bodor, D. Rose, T. A. Farley, C. Swalm, and S. K. Scott, "Neighbourhood fruit and vegetable availability and consumption: the role of small food stores in an urban environment," Public Health Nutrition, vol. 11, no. 4, pp. 413-420, 2008 . 
[35] D. Rose and R. Richards, "Food store access and household fruit and vegetable use among participants in the US Food Stamp Program," Public Health Nutrition, vol. 7, no. 8, pp. 1081-1088, 2004.

[36] StataCorp, Stata Statistical Software: Release 10, StataCorp, College Station, Tex, USA, 2007.

[37] M. F. Folstein, S. E. Folstein, and P. R. McHugh, “'Mini mental state'. A practical method for grading the cognitive state of patients for the clinician," Journal of Psychiatric Research, vol. 12, no. 3, pp. 189-198, 1975.

[38] R. C. Petersen, J. C. Stevens, M. Ganguli, E. G. Tangalos, J. L. Cummings, and S. T. DeKosky, "Practice parameter: early detection of dementia: mild cognitive impairment (an evidence-based review)," Neurology, vol. 56, no. 9, pp. 11331142, 2001.

[39] T. L. Brink, J. A. Yesavage, and O. Lum, "Screening tests for geriatric depression," Clinical Gerontologist, vol. 1, no. 1, pp. 37-44, 1982.

[40] J. A. Yesavage, T. L. Brink, and T. L. Rose, "Development and validation of a geriatric depression screening scale: a preliminary report," Journal of Psychiatric Research, vol. 17, no. 1, pp. 37-49, 1982.

[41] J. M. Oakes and P. H. Rossi, "The measurement of SES in health research: current practice and steps toward a new approach," Social Science and Medicine, vol. 56, no. 4, pp. 769784, 2003.

[42] M. Hall, D. J. Buysse, E. A. Nofzinger et al., "Financial strain is a significant correlate of sleep continuity disturbances in latelife," Biological Psychology, vol. 77, no. 2, pp. 217-222, 2008.

[43] A. Rosengren, S. Hawken, S. Ounpuu et al., "Association of psychosocial risk factors with risk of acute myocardial infarction in 11119 cases and 13648 controls from 52 countries (the INTERHEART study): case-control study," The Lancet, vol. 364, no. 9438, pp. 953-962, 2004.

[44] S. V. Kasl, "Stress and health," Annual Review of Public Health, vol. 5, pp. 319-341, 1984.

[45] S. L. Szanton, J. M. Gill, and J. K. Allen, "Allostatic load: a mechanism of socioeconomic health disparities?" Biological Research for Nursing, vol. 7, no. 1, pp. 7-15, 2005.

[46] V. L. Shavers, "Measurement of socioeconomic status in health disparities research," Journal of the National Medical Association, vol. 99, no. 9, pp. 1013-1023, 2007.

[47] E. Grundy and G. Holt, "The socioeconomic status of older adults: how should we measure it in studies of health inequalities?" Journal of Epidemiology and Community Health, vol. 55, no. 12, pp. 895-904, 2001.

[48] S. A. Robert, D. Cherepanov, M. Palta, N. C. Dunham, D. Feeny, and D. G. Fryback, "Socioeconomic status and age variations in health-related quality of life: results from the national health measurement Study," Journals of Gerontology, vol. 64, no. 3, pp. 378-389, 2009.

[49] J. L. Wang, N. Schmitz, and C. S. Dewa, "Socioeconomic status and the risk of major depression: the Canadian national population health survey," Journal of Epidemiology and Community Health, vol. 64, no. 5, pp. 447-452, 2010.

[50] L. M. Dinour, D. Bergen, and M. C. Yeh, "The food insecurityobesity paradox: a review of the literature and the role food stamps may play," Journal of the American Dietetic Association, vol. 107, no. 11, pp. 1952-1961, 2007.

[51] L. P. Fried, L. Ferrucci, J. Darer, J. D. Williamson, and G. Anderson, "Untangling the concepts of disability, frailty, and comorbidity: implications for improved targeting and care," Journals of Gerontology, vol. 59, no. 3, pp. 255-263, 2004.

[52] J. W. Rowe and R. L. Kahn, "Human aging: usual and successful," Science, vol. 237, no. 4811, pp. 143-149, 1987. 


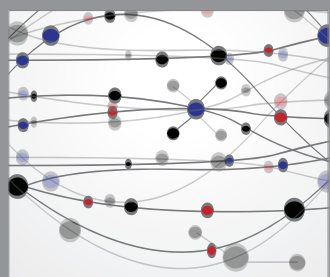

The Scientific World Journal
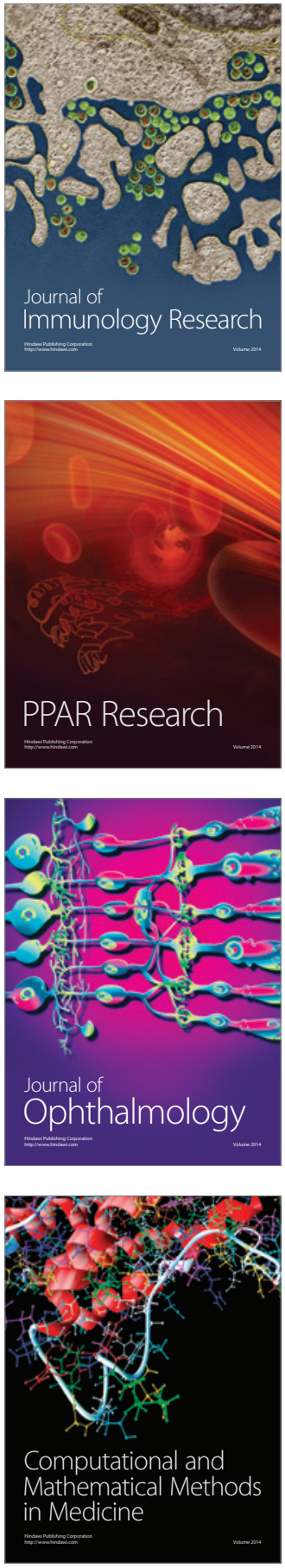

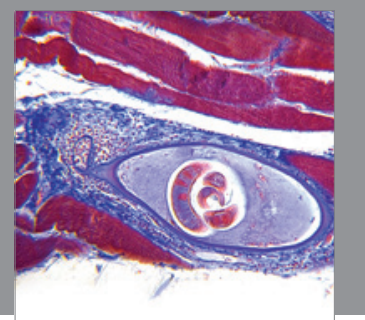

Gastroenterology

Research and Practice
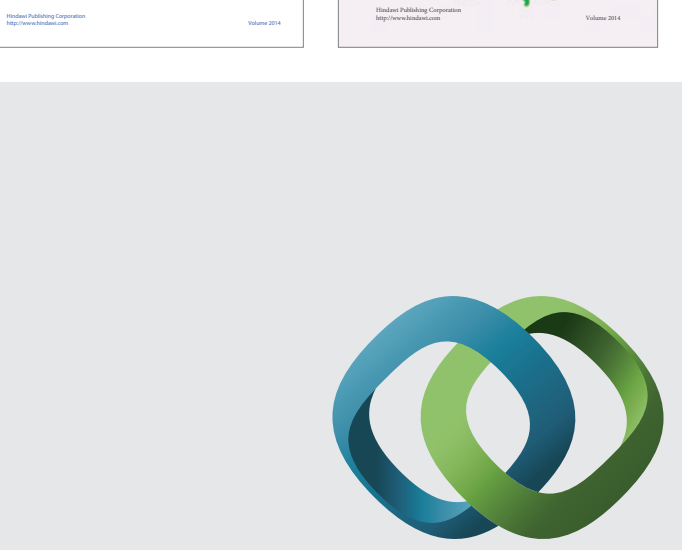

\section{Hindawi}

Submit your manuscripts at

http://www.hindawi.com
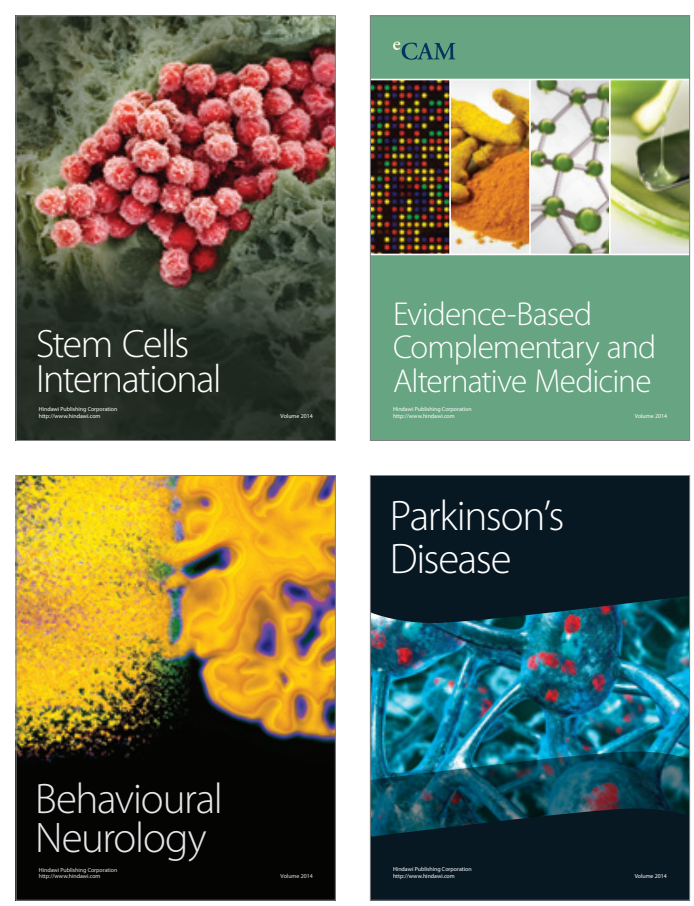

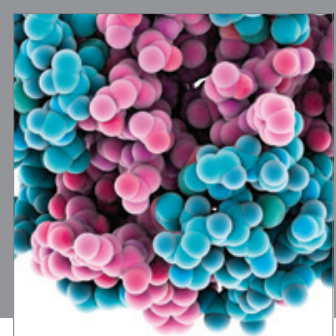

Journal of
Diabetes Research

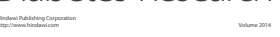

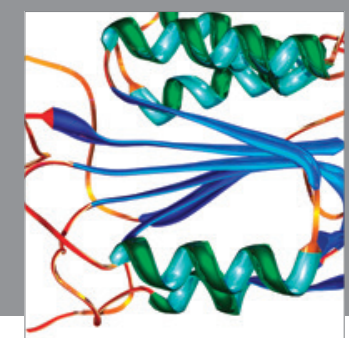

Disease Markers
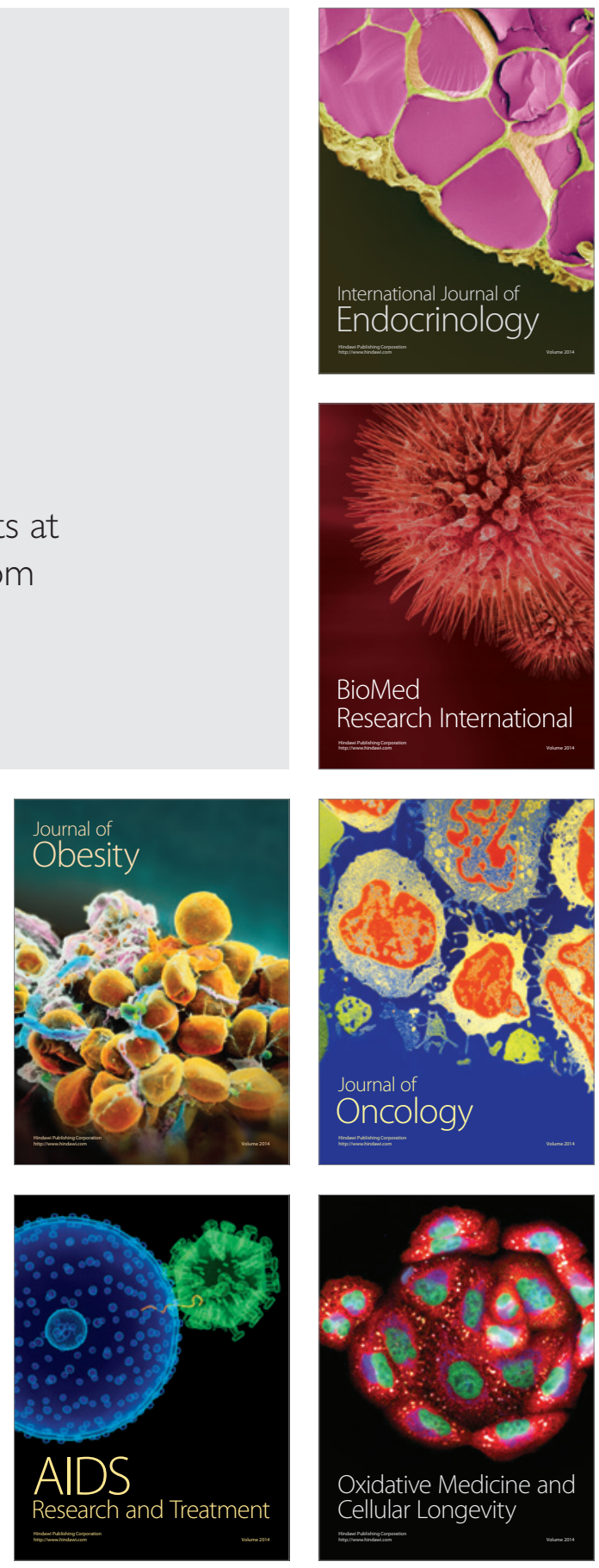